\title{
Screening of Antianxiety Activity of Abies pindrow Royle Aerial Parts
}

\author{
Kumar D and Kumar Suresh* \\ Department of Pharmaceutical Sciences and Drug Research, Punjabi University, Patiala-147 002, Punjab, India
}

\begin{abstract}
Abies pindrow Royle (Himalayan Silver Fir; Pinaceae) has been traditionally used for the treatment for anxiety but the plant has not been systematically investigated to validate its traditional claims. Thus, it was planned to investigate antianxiety activity of various extracts and fractions of $A$. pindrow aerial parts using elevated plus maze model (EPM). Properly identified $A$. pindrow aerial parts were successively and exhaustively extracted using solvents in increasing order of polarity viz., n-hexane, chloroform, methanol and water. All crude extracts were subjected to antianxiety activity at the doses of 100,200 or $400 \mathrm{mg} / \mathrm{kg}$, p.o. in mice. Efficacy of $A$. pindrow was statistically compared with the standard anxiolytic drug, diazepam ( $2 \mathrm{mg} / \mathrm{kg}$, i.p.). Amongst various extracts, chloroform and methanol extract exhibited significant antianxiety activity with respect to control, and statistically equivalent to the standard drug at the dose of 200 and $400 \mathrm{mg} / \mathrm{kg}$, respectively. The bioactive methanol extract was partitioned successively using solvents in increasing order of polarity viz., n-hexane, ethyl acetate and 1-butanol. All fractions were also subjected to antianxiety activity at the doses of $25 \mathrm{or} 50 \mathrm{mg} / \mathrm{kg}, p . o$. in mice. Only ethyl acetate fraction (EAF) exhibited significant antianxiety activity equivalent to the standard drug at the dose $50 \mathrm{mg} / \mathrm{kg}$. Present studies scientifically validated traditional claims of $A$. pindrow for antianxiety activity. Flavonoids of $A$. pindrow aerial parts have been suggested to play role in treating anxiety disorders.
\end{abstract}

Keywords: Abies pindrow, Anxiolytic, Diazepam, Elevated plus maze.

\section{INTRODUCTION}

Global scenario of persons afflicted by mental disorders is alarming. ${ }^{1}$ About 500 million people suffer from neurotic, stress related and somatoform problems, 200 million from mood disorders, 83 million from mental retardation, 30 million from epilepsy, 22 million from dementia, and 16 million from schizophrenia. Anxiety disorders are serious medical illnesses that have affected $1 / 8^{\text {th }}$ of total population worldwide irrespective of gender, age, religion, nationality and profession. ${ }^{2}$

Anxiety Disorders Association of America (ADAA) described anxiety disorders as the most common mental illness in the US that have affected 19.1 million $(13.3 \%)$ of the adult (18-54 years) US population. ${ }^{3}$ In India, prevalence rate for all mental disorders is 65.4 per 1000 population, and that for anxi- ety neurosis is 18.5 per 1000 population. ${ }^{4}$ The Global Research on Anxiety and O fauna is so vast that the Indian scientists are investigating plants, based on their use in traditional system of medicine, for the treatment of neurological disorders.

Abies pindrow Royle (Himalayan Silver Fir; Pinaceae) is a plant which has long tradition of use in the treatment of anxiety. ${ }^{7}$ It is widely distributed at elevations between 2000-3000 $\mathrm{m}$ throughout the Western Himalayas from Afghanistan to Nepal.,9 have suggested role of $A$. pindrow aerial parts in treating anxiety disorders, but uncharacterized crude extracts of $A$. pindrow aerial parts have been employed in this pharmacological investigation. ${ }^{9}$ Therefore, systematic research is needed on $A$. pindrow aerial parts to validate traditional
Submission Date: 12/09/2014 Revision Date : :30/10/2014 Accepted Date : 09/12/2014

DOI: 10.5530/ijper.49.1.9 Correspondence Address Dr. Suresh Kumar Department of

Pharmaceutical Sciences and Drug Research,

Punjabi University,

Patiala-147 002,

Punjab, India.

E-mail: thakur_pu@yahoo. com

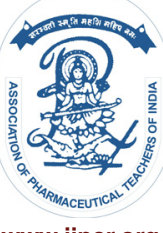

www.ijper.org 
claims especially for anxiety disorders. Present research work reported by the authors is different from previous study as: (a) various extracts of $A$. pindrow aerial parts have been prepared successively for evaluation of antianxiety activity; (b) fractionation of bioactive extract has been done to purify crude extract; (c) specific class of phytoconstituents responsible for activities and their probable modes of action have been suggested.

\section{MATERIALS AND METHODS}

\section{Collection and identification of plant material}

Abies pindrow aerial parts were collected form Gulaba Kothi, Manali at a height of 2000-2100 m, India in September, 2012. Identity of the plant was confirmed by Dr. Sunita Garg, Chief Scientist and Head, Raw Materials Herbarium and Museum, National Institute of Science Communication and Information Resources (NISCAIR), New Delhi (Reference no. - NISCAIR/RHMD/Consult/2013/2242/23, dated 21/05/2013).

\section{Solvents}

Methanol (S.D. Fine Chemicals, Mumbai, India), chloroform, n-hexane, 1-butanol and ethyl acetate (E Merck, Delhi, India) of LR grade were used for preparing various crude extracts and fractions of $A$. pindrow aerial parts.

\section{Preparation of extracts and fractions}

A. pindrow aerial parts were dried under sunlight and powdered in a grinder. Dried powdered plant material $(2 \mathrm{~kg})$ was extracted in a Soxhlet apparatus successively using solvents in increasing order of polarity viz., n-hexane, chloroform and methanol. Water extract was prepared by boiling the marc of plant material with distilled water for $2 \mathrm{~h}$ on a hot plate. Solvents and water from crude extracts were recovered under reduced pressure using rotary vacuum evaporator (BUCHI, Switzerland) to get $\mathrm{n}$-hexane extract (HE), chloroform extract (CE), methanol extract (ME) and water extract (WE).

The bioactive extract (100 g) of plant material was suspended uniformly in water, placed in a round bottom flask, and partitioned successively using solvents in increasing order of polarity viz, n-hexane, ethyl acetate and 1-butanol by heating at $50^{\circ} \mathrm{C}$ for 30 min along with continuous stirring. This procedure of partitioning with each solvent was repeated eight more times. All the separated layers of every solvent were pooled and concentrated under reduced pressure to get $n$-hexane fraction (HF), ethyl acetate fraction (EAF), 1-butanol fraction (BF) and remaining bioactive extract (RBE). Various extracts and fractions were subjected to phytochemical screening to ascertain various classes of phytoconstituents present therein. ${ }^{10}$

\section{Animals}

Laca mice (either sex) of body weight 20-25 g purchased from the Central Research Institute, Kasauli, India were used for antianxiety activity studies. The animals were fed with normal laboratory pellet diet and water ad libitum. Approval was taken from Institutional Animal Ethics Committee of Punjabi University, Patiala before carrying out animal studies (107/99/CPCSEA/2013-52, dated 18/10/2013). Mice were acclimatized to laboratory conditions by housing them daily in the laboratory for $1 \mathrm{~h}$ for seven consecutive days before the start of experiment. All the experiments were carried between $9 \mathrm{AM}$ to 12 PM as per the guidelines of Committee for the Purpose of Control and Supervision on Experiments on Animals. Mice were fasted overnight before use. Test drugs were administered orally with the help of an oral cannula fitted on a tuberculin syringe.

\section{Vehicle and standard drug}

Distilled water + Tween $80(2 \%)$ was used as vehicle for preparing various test doses of various extracts, fractions and isolates in such a concentration as to administer a volume ranging 0.2 to $0.25 \mathrm{ml}$ to the mice. Diazepam (Triko Pharmaceuticals, Rohtak, Haryana) was used as standard antianxiety drug at a dose of $2 \mathrm{mg} / \mathrm{kg}$, i.p.

\section{Experimental design}

Two experimental protocols were designed. A total of 24 groups of mice were made, and each group comprised 6 mice.

Experimental protocol I, comprising groups I to XIV, was designed to assess antianxiety activity of crude extracts of $A$. pindrow aerial parts.

- Group I - Control, received vehicle $(0.25 \mathrm{ml}$, p.o.).

- Group II - Standard, received diazepam (2 mg/ $\mathrm{kg}$, i.p.).

- Groups III to V - Test, received 100, 200 or 400 $\mathrm{mg} / \mathrm{kg}$ doses of $\mathrm{HE}$ respectively.

- Groups VI to VIII - Test, received 100, 200 or $400 \mathrm{mg} / \mathrm{kg}$ doses of CE respectively.

- Groups IX and XI - Test, received 100, 200 or $400 \mathrm{mg} / \mathrm{kg}$ doses of ME respectively. 
- Groups XII and XIV - Test, received 100, 200 or $400 \mathrm{mg} / \mathrm{kg}$ doses of WE respectively.

Experimental protocol II, comprising groups I to X, was designed to assess antianxiety activity of various fractions obtained from bioactive extract of $\mathrm{A}$. pindrow aerial parts.

- Group I - Control, received vehicle $(0.25 \mathrm{ml}$, p.o.).

- Group II - Standard, received diazepam (2 mg/ kg, i.p.).

- Groups III and IV - Test, received 25 or $50 \mathrm{mg} /$ $\mathrm{kg}$ doses of $\mathrm{HF}$ respectively.

- Groups V and VI - Test, received 25 or $50 \mathrm{mg} /$ $\mathrm{kg}$ doses of EAF respectively.

- Groups VII and VIII - Test, received 25 or 50 $\mathrm{mg} / \mathrm{kg}$ doses of BF respectively.

- Groups IX and X - Test, received 25 or $50 \mathrm{mg} /$ $\mathrm{kg}$ doses of RBE respectively.

\section{Evaluation of antianxiety activity using elevated plus maze (EPM)}

EPM consisting of two open arms $(16 \times 5 \mathrm{~cm})$ and two closed arms $(16 \times 5 \times 12 \mathrm{~cm})$ having an open roof, with the plus-maze elevated $(25 \mathrm{~cm})$ from the floor was used to observe anxiolytic behaviour in animals. ${ }^{11}$ Each mouse was placed at the centre of the elevated plus maze with its head facing the open arms, $45 \mathrm{~min}$ after the treatments. During the $5 \mathrm{~min}$ experiment, number of entries into the open arms and average time spent by the mouse in the open arms (average time $=$ total time spent in open arms/ number of entries in arms) were recorded in mice.

\section{Statistics}

The results have been expressed as mean \pm standard deviation (SD). The test drugs were compared with standard drug and control by one way analysis of variance (ANOVA) followed by Student Newman Keul's test. ${ }^{12}$

\section{RESULTS}

Yields of $\mathrm{HE}, \mathrm{CE}, \mathrm{ME}$ and WE were found to be $3.20,4.10,10.60$ and $16.10 \%$, respectively. All extracts were screened for different classes of phytoconstituents. The results of phytochemical screening showed presence of lipids in HE; triterpenoids in CE; triterpenoids, steroids, flavonoids, carbohydrates and proteins in ME; tannins, saponins, carbohydrates and proteins in water extract.

All extracts of $A$. pindrow aerial parts were subjected to antianxiety activity screening in mice using EPM. Table 1 shows the mean number of entries and mean time spent in open arms of EPM by mice after administration of 100,200 or $400 \mathrm{mg} / \mathrm{kg}$, doses of crude extracts, diazepam $(2 \mathrm{mg} / \mathrm{kg})$ and vehicle. Amongst various extracts, $\mathrm{CE}$ and $\mathrm{ME}$ exhibited significant antianxiety activity with respect to control. $\mathrm{HE}$ and WE were found to be devoid of antianxiety activity. Though, 200 or $400 \mathrm{mg} / \mathrm{kg}$ doses of ME significantly increased number of entries and time spent in open arms in mice with respect to control, but statistically equivalent anxiolytic activity to the

\begin{tabular}{|c|c|c|c|}
\hline Treatment & Dose $(\mathrm{mg} / \mathrm{kg})$ & $\begin{array}{c}\text { Number of entries in open } \\
\text { arms } \\
\text { Mean } \pm \text { S.D. }\end{array}$ & $\begin{array}{l}\text { Time spent in open arms } \\
\text { (sec) } \\
\text { Mean } \pm \text { S.D. }\end{array}$ \\
\hline Control & Vehicle & $2.33 \pm 0.51^{a}$ & $3.89 \pm 0.57^{a}$ \\
\hline Standrad drug (Diazepam) & 2 & $8.00 \pm 1.79^{*}$ & $12.99 \pm 1.55^{*}$ \\
\hline \multirow[t]{3}{*}{ HE } & 100 & $2.50 \pm 0.55^{a}$ & $3.83 \pm 0.50^{a}$ \\
\hline & 200 & $2.66 \pm 0.52^{a}$ & $3.96 \pm 0.19^{a}$ \\
\hline & 400 & $2.83 \pm 0.41^{a}$ & $4.03 \pm 1.04^{a}$ \\
\hline \multirow[t]{3}{*}{ CE } & 100 & $5.66 \pm 0.51^{* a}$ & $8.36 \pm 1.02^{* a}$ \\
\hline & 200 & $7.50 \pm 1.64^{*}$ & $12.30 \pm 1.31^{*}$ \\
\hline & 400 & $7.66 \pm 0.82^{*}$ & $12.41 \pm 1.86^{*}$ \\
\hline \multirow[t]{3}{*}{ ME } & 100 & $4.50 \pm 0.55^{* a}$ & $6.94 \pm 0.92^{* a}$ \\
\hline & 200 & $5.83 \pm 1.17^{* a}$ & $10.03 \pm 1.16^{* a}$ \\
\hline & 400 & $7.83 \pm 1.72^{*}$ & $12.37 \pm 1.34^{*}$ \\
\hline \multirow[t]{3}{*}{ WE } & 100 & $2.16 \pm 0.41^{a}$ & $3.83 \pm 0.57^{a}$ \\
\hline & 200 & $2.33 \pm 0.52^{\mathrm{a}}$ & $3.99 \pm 0.49^{a}$ \\
\hline & 400 & $2.66 \pm 0.82^{a}$ & $4.66 \pm 0.58^{a}$ \\
\hline
\end{tabular}




\begin{tabular}{|l|c|c|}
\hline \multicolumn{2}{|c|}{ Table 2: Antianxiety activity, using EPM, of various fractions obtained from methanol extract of A. pindrow aerial } \\
parts.
\end{tabular}

standard drug was observed only at the dose of 400 $\mathrm{mg} / \mathrm{kg}$. Mice treated with CE (200 or $400 \mathrm{mg} / \mathrm{kg}$ ) showed significant increase in number of entries and time spent in open arms of EPM in comparison to the control group, and the activity was equivalent to the standard group. The bioactive methanol extract was further fractionated using solvents in increasing order of polarity viz., n-hexane, ethyl acetate and 1-butanol. Yields of HF, EAF, BF and RBE were found to be $6.89,18.66,14.76$ and $55.49 \%$, respectively. Phytochemical screening of various fractions showed presence of steroids in HF; flavonoids and triterpenoids in EAF. Various fractions of bioactive extract were subjected to antianxiety activity screening in mice using EPM. Table 2 shows the mean number of entries and mean time spent in open arms of EPM by mice after administration of 25 or $50 \mathrm{mg} / \mathrm{kg}$, doses of fractions, diazepam $(2 \mathrm{mg} / \mathrm{kg})$ or vehicle. Amongst various fractions, only EAF exhibited significant antianxiety activity at the dose of $50 \mathrm{mg} / \mathrm{kg}$ with respect to control, and the activity was equivalent to the standard drug. HF and RBE were devoid of antianxiety activity. Although, the antianxiety activity of BF was statistically insignificant with respect to the standard group, yet it was statistically significant with respect to the control group. This observation confirms mild antianxiety activity of BF.

\section{DISCUSSION}

Anti-anxiety activity of various extracts/fractions of A. pindrow aerial parts was evaluated using well established model, i.e., EPM. The model was chosen since it is effective, cheap, simple, less time consuming, and requires no preliminary training to the mice and does not cause much discomfort to the animals while handling. ${ }^{13}$ The ultimate manifestation of anxiety due to height in the animals is exhibited by decrease in motor activity, which is measured by number of entries and average time spent in the open arms of EPM by the mice. ${ }^{14}$

Various extracts of $A$. pindrow aerial parts were evaluated for antianxiety activity. Amongst various extracts, chloroform and methanol extract exhibited significant antianxiety activity with respect to control and equivalent to the standard drug at the dose level of 200 and $400 \mathrm{mg} / \mathrm{kg}$, respectively. Therefore, bioactive methanol extract was fractionated using standardized procedure to get HF, EAF and BF. All fractions were also subjected to antianxiety activity screening at doses of 25 or $50 \mathrm{mg} / \mathrm{kg}$, p.o. in mice. Only EAF exhibited significant antianxiety activity which was equivalent to the standard drug diazepam at the dose $50 \mathrm{mg} / \mathrm{kg}$ whereas BF exhibited mild antianxiety activity at the dose of $50 \mathrm{mg} / \mathrm{kg}$.

It is suggested that the antianxiety activity of extracts and fractions of $A$. pindrow aerial parts could be attributed to inhibition of $\gamma$-amino butyric acid transmission, ${ }^{15}$ binding to benzodiazepine receptors as agonist, ${ }^{16}$ or their ability to increase ascorbic acid level in brain ${ }^{17}$ and monoamine oxidase inhibition. ${ }^{18}$ Preliminary phytochemical studies showed presence of flavonoids and triterpenoids in bioactive extracts / fractions of $A$. pindrow aerial parts.

Our results are in agreement with the reported literature where flavonoids - quercetin, ${ }^{18}$ kaempferol ${ }^{19}$ and apigenin; ${ }^{20}$ and triterpenoids - galphimine A, galphimine $\mathrm{B}^{21}$ and $a, \beta$-amyrin ${ }^{22}$ have been reported to exhibit anxiolytic activity. It is finally suggested that flavonoids and / or triterpenoids are responsible for anxiolytic activity of $A$. pindrow aerial parts. Detailed investigations are in progress to isolate bioactive constituent(s) from bioac- 
tive methanol extract and EAF of $A$. pindrow aerial parts following antianxiety activity-guided fractionation.

\section{CONFLICT OF INTEREST}

The authors report no declaration of interest.

\section{ACKNOWLEDGEMENT}

The financial assistance provided by University Grants Commission, New Delhi to Dr Suresh Kumar for the present research work is duly acknowledged.

\section{REFERENCES}

1. Barbotte E, Guillemin F, Chan N. Prevalence of impairments, disabilities, handicaps and quality of life in the general population: A review of recent literature. Int J Public Health. 2001; 79(11): 1047.

2. NIMH. The numbers count: Mental disorders in America. Bethesda, Maryland: National Institute of Mental Health, Office of Communications; 2011. Through http:// www.nimh.nih.gov/.

3. ADAA. Fact and statistics, anxiety disorders association of America. Maryland, USA: Silver Spring; 2011. Through www.adaa.org/mediaroom/ index.cfm.

4. Madhav S. Epidemiological study of prevalence of mental disorders in India. Indian J Community Med. 2001; 26(4): 198.

5. GRAD. Anxiety may be next major global health problem, global research on anxiety and depression network. New Orleans, Los Angeles: American Psychiatric Association, Consultancy Group Incorporation; 2001.

6. Baldessarini RJ. Drugs and the treatment of psychiatric disorders. In: Hardman JG, Limbird, LE, editors. Goodman and Gilman's The Pharmacological Basis of Therapeutics. New York: McGraw-Hill; 2001, 987.

7. Quattrocchi U. CRC world dictionary of medicinal and poisonous plants: Common names, scientific names, eponyms, synonyms and etymology. Boca Raton, USA: CRC Press; 2012.
8. Kirtikar KR, Basu BD. Indian medicinal plants. Allahabad, India: International Book Distributors; 1975.

9. Singh RK, Nath G, Goel RK, Bhattacharya SK. Pharmacological actions of Abies pindrow Royle leaf. Indian J Exp Biol. 1998; 36(2): 187-91.

10. Farnsworth NR. Biological and chemical screening of plants. J Pharma Sci. 1966; 55(3): 225-76

11. Kulkarni SK. Handbook of experimental pharmacology. 3rd ed. New Delhi: Vallabh Prakashan, Pitampura; 2003.

12. Scheffer WC. Statistics for the biological sciences. 32nd ed. Philippines: Addison-Wesley Publishing Company; 1980.

13. Madaan R, Sharma A. Evaluation of antianxiety activity of Actaea spicata Linn. Int J Pharm Sci Drug Res. 2011; 3(1): 45-7.

14. Belzung $\mathrm{C}$, Griebel $\mathrm{G}$. Measuring normal and pathological anxiety like behaviour in mice: A review. Behav Brain Res. 2001; 125(2): 141-9.

15. Une HD, Sarveiya VP, Pal SC, Kasture VS, Kasture SB. Nootropic and anxiolytic activity of saponins of Albizzia lebbeck leaves. Pharmacol Biochem Behav. 2001; 69(3-4): 439-44.

16. Bergendorff $O$, Dekermendjian $K$, Nielsen $M$, Shan $R$, Witt $R$, Ai J, et al. Furanocoumarins with affinity to brain benzodiazepine receptors in vitro. Phytochemistry 1997; 44(6): 1121-4.

17. Yanpallewar S, Rai S, Kumar M, Chauhan S, Acharya SB. Neuroprotective effect of Azadirachta indica on cerebral post-ischemic reperfusion and hypoperfusion in rats. Life Sci. 2005; 76(12): 1325-38.

18. Saaby L, Rasmussen HB, Jager AK. MAO-A inhibitory activity of quercetin from Calluna vulgaris (L.) Hull. J Ethnopharmacol. 2009; 121(1): 178-81.

19. Grundmann O, Nakajima J, Kamata K, Seo S, Butterweck V. Kaempferol from the leaves Apocynum venetum possesses anxiolytic activities in the elevated plus maze test in mice. Phytomedicine 2009; 16(4): 295-302.

20. Kumar S, Sharma A. Apigenin: The anxiolytic constituent of Turnera aphrodisiaca. Pharm Biol. 2006; 44(2): 84-90.

21. Herrera-Ruiz M, Gonzalez-Cortazar M, Jimenez-Ferrer E, Zamilpa A, Alvarez L, Ramirez G, et al. Anxiolytic effect of natural galphimines from Galphimia glauca and their chemical derivatives. J Nat Prod. 2006; 69(1): 59-61.

22. Aragao GF, Carneiro LM, Junior AP, Vieira LC, Bandeira PN, Lemos TL, Viana GS. A possible mechanism for anxiolytic and antidepressant effects of alpha- and beta-amyrin from Protium heptaphyllum (Aubl.) March. Pharmacol Biochem Behav. 2006; 85(4): 827-34. 